\title{
Giant arteriovenous malformation presenting as pediatric task-specific dystonia
}

回的

\section{Figure 1 Left vertebral artery (LVA) angiogram, sagittal T2 MR imaging, and MRA}

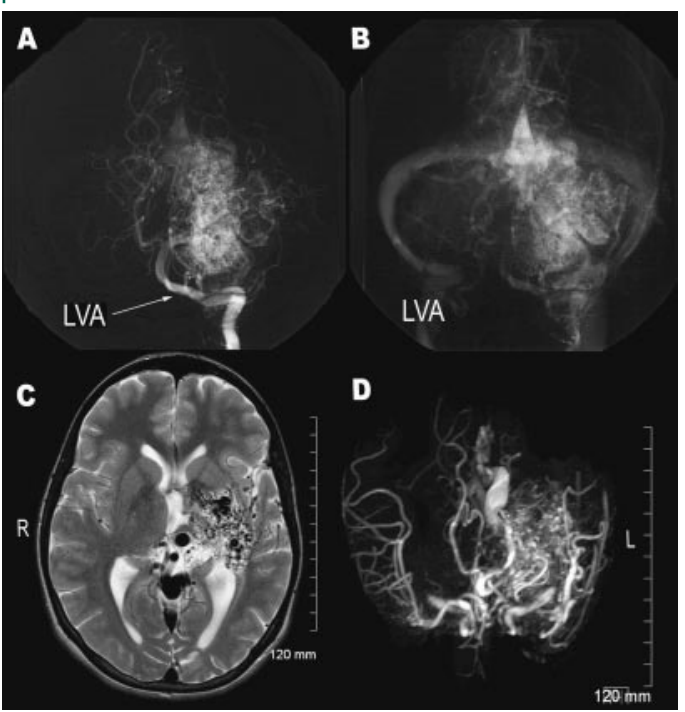

Arterial (A) and venous phase (B) of the LVA angiogram in anteroposterior view showing the giant arteriovenous malformation (AVM) that involves the left thalamus and putamen and extends to the left medial temporal lobe. The giant AVM presented as task-specific dystonia that progressed to right hemidystonia. (C) Sagittal T2 MR imaging demonstrates the large left cerebral hemispheric AVM involving the left temporal lobe, left basal ganglia, and left thalamus. (D) MRA demonstrates the large tangle of vessels in the left hemisphere consistent with the AVM.

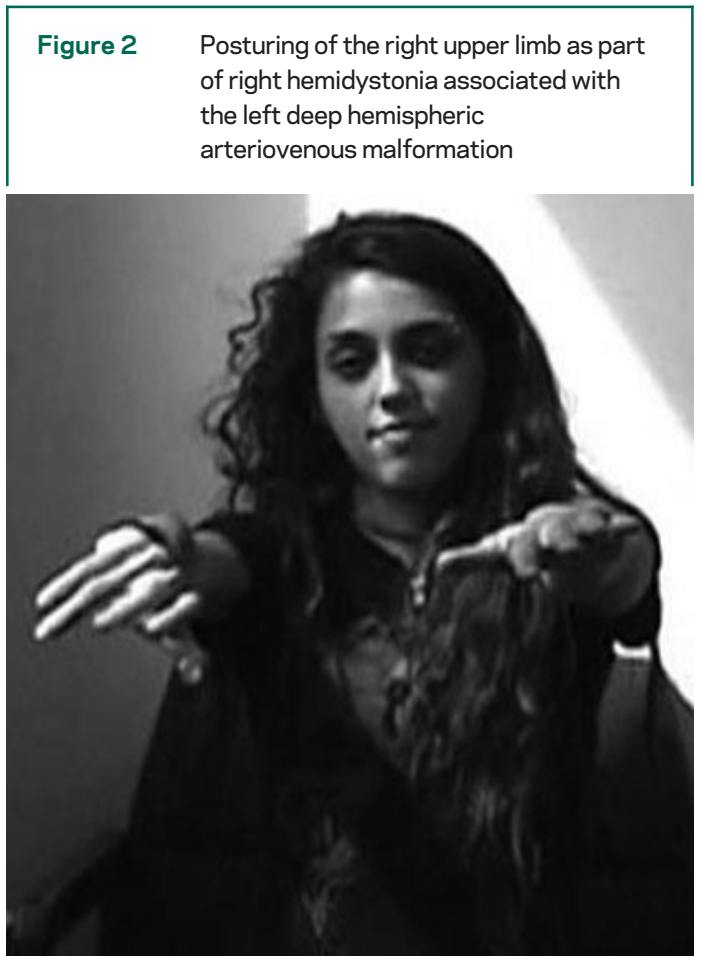

An 11-year-old girl presented with difficulties writing and playing the flute for 6 months. Her dystonic symptoms progressively involved her right shoulder and arm muscles, and by age 16 right hemidystonia was diagnosed (see video on the Neurology ${ }^{\circledR}$ Web site at www.neurology.org). Brain MRI revealed a Spetzler-Martin grade V $(>6 \mathrm{~cm})^{1}$ left deep hemispheric arteriovenous malformation (AVM). Arteriography confirmed the finding (figure 1). Embolizations did not produce clinical benefit. Surgical radiotherapy and deep brain stimulation were contraindicated. Oral medications failed to control symptoms and botulinum toxin type A injections improved dystonia but were associated with limb weakness. Although rare, ${ }^{2}$ AVMs should be considered in the differential diagnosis of pediatric taskspecific dystonia (figure 2).

Spiridon Papapetropoulos, MD, PhD, Carlos Singer, MD, Cenk Sengun, MD, and Bruno V. Gallo, Miami, FL

Disclosure: The authors report no conflicts of interest.

Address correspondence and reprint requests to Dr. Spiridon Papapetropoulos, Department of Neurology, University of Miami, Miller School of Medicine, 1501 NW 9th Avenue (NPF), Room 2017, Miami, FL 33136; spapapetropoulos@med. miami.edu

Supplemental data at www.neurology.org
1. Spetzler RF, Martin NA. A proposed grading system for arteriovenous malformations. J Neurosurg 1986;65:476-483.

2. Kurita H, Sasaki T, Suzuki I, Kirino T. Basal ganglia arteriovenous malformation presenting as "writer's cramp." Childs Nerv Syst 1998;14:285-287. 


\section{Neurology}

Giant arteriovenous malformation presenting as pediatric task-specific dystonia

Spiridon Papapetropoulos, Carlos Singer, Cenk Sengun, et al.

Neurology 2008;70;1294

DOI 10.1212/01.wnl.0000306637.14628.76

\section{This information is current as of April 7, 2008}

\section{Updated Information \&}

Services

Supplementary Material

References

Subspecialty Collections

Permissions \& Licensing

Reprints including high resolution figures, can be found at:

http://n.neurology.org/content/70/15/1294.full

Supplementary material can be found at:

http://n.neurology.org/content/suppl/2008/04/07/70.15.1294.DC1

This article cites 2 articles, 0 of which you can access for free at: http://n.neurology.org/content/70/15/1294.full\#ref-list-1

This article, along with others on similar topics, appears in the following collection(s):

Arteriovenous malformation

http://n.neurology.org/cgi/collection/arteriovenous_malformation

\section{Dystonia}

http://n.neurology.org/cgi/collection/dystonia

Information about reproducing this article in parts (figures,tables) or in its entirety can be found online at:

http://www.neurology.org/about/about_the_journal\#permissions

Information about ordering reprints can be found online:

http://n.neurology.org/subscribers/advertise

Neurology ${ }^{\circledR}$ is the official journal of the American Academy of Neurology. Published continuously since 1951, it is now a weekly with 48 issues per year. Copyright . All rights reserved. Print ISSN: 0028-3878. Online ISSN: 1526-632X.

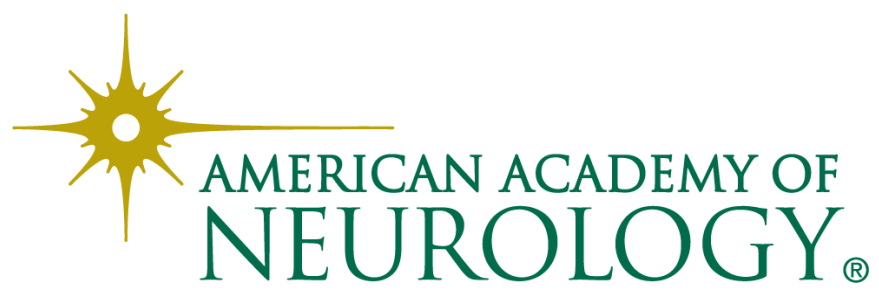

